\title{
Evaluation of Antibacterial Activity of Essential Oils of Melaleuca cajuputi Powell
}

\author{
Noor Zarina Abd Wahab ${ }^{1 *}$ (D) Nur Saidatul Aqilah Ja'afar ${ }^{2}$ and \\ Samhani Binti Ismail ${ }^{3}$ \\ ${ }^{1}$ School of Biomedicine, Faculty of Health Sciences, Universiti Sultan Zainal Abidin, Kuala Nerus, \\ Terengganu, Malaysia. \\ ${ }^{2}$ School of Health Sciences, Universiti Sains Malaysia Health Campus, Kubang Kerian, Kelantan, Malaysia. \\ ${ }^{3}$ Faculty of Medicine, Universiti Sultan Zainal Abidin, Kuala Terengganu, Terengganu, Malaysia.
}

\begin{abstract}
Melaleuca cajuputi Powell is a tree species belonging to the family Myrtaceae and is widely used in traditional medicine. This study was conducted to investigate the antibacterial activities of essential oils of $M$. cajuputi Powell. Antibacterial activity was tested against Gram positive and Gram negative bacteria using the agar disc diffusion method. The essential oils of $M$. cajuputi were found to exert antibacterial activity against all of the tested bacteria, including Staphylococcus aureus, Streptococcus pyogenes, methicillin-resistant Staphylococcus aureus (MRSA), Klebsiella pneumoniae, and Escherichia coli. The zones of inhibition for S. aureus, S. pyogenes, MRSA, E. coli, and K. pneumoniae were 12.7 $\mathrm{mm}, 10.7 \mathrm{~mm}, 10.0 \mathrm{~mm}, 8.7 \mathrm{~mm}$ and $9.3 \mathrm{~mm}$ respectively, against $0.714 \%(\mathrm{w} / \mathrm{w})$ of the essential oils. These results highlighted that Gram negative bacteria are less susceptible to the essential oils of $M$. cajuputi. A large zone of inhibition might be a sign of a leaching antimicrobial agent. These findings suggest that $M$. cajuputi is a potential natural antibacterial agent.
\end{abstract}

Keywords: Melaleuca cajuputi Powell, essential oils, antibacterial, minimum inhibitory concentration

\footnotetext{
*Correspondence: zarinawahab@unisza.edu.my

(Received: October 25, 2021; accepted: January 1, 2022)

Citation: Abd Wahab NZ, Ja'afar NSA, Ismail SB. Evaluation of Antibacterial Activity of Essential Oils of Melaleuca cajuputi Powell. J Pure App/ Microbiol. 2022;16(1):549-556. doi: 10.22207/JPAM.16.1.52

(C) The Author(s) 2022. Open Access. This article is distributed under the terms of the Creative Commons Attribution 4.0 International License which permits unrestricted use, sharing, distribution, and reproduction in any medium, provided you give appropriate credit to the original author(s) and the source, provide a link to the Creative Commons license, and indicate if changes were made.
} 


\section{INTRODUCTION}

Essential oils are highly concentrated, unstable substances found in plants. They have a distinctive fragrance with a high refractive index owing to ethers, aldehydes, terpenes, esters, ketones, phenols, and alcohols. ${ }^{1}$ Most essential oils are colorless or pale yellow in color and are liquid at room temperature. Essential oils are a mixture of volatile compounds that exclude saponins, flavonoids, tannins, steroids, terpenoids, and alkaloids. ${ }^{2}$ Notably, essential oils are significant in folk herbal medicines, cosmetic products, aromatics, perfumes, and phototherapy. ${ }^{3}$ Moreover, they are well known for their antimicrobial properties and are also effective in treating diseases such as carcinoma, Alzheimer's disease, cardiovascular disease, discomfort, pregnancy, and insomnia. ${ }^{4,5}$ The secondary metabolites in essential oils play a critical role in plant protection, as they regularly have antimicrobial characteristics.

Melaleuca cajuputi Powell is a member of the Myrtaceae family and is prominently known as gelam, white tree, cajeput oil tree, tea tree, or paper bark tree. M. cajuputi is commonly present in swampy ground close to the coasts and is frequently found in tropical countries, such as Malaysia, Indonesia, Vietnam, Thailand, Myanmar, and northern Australia. ${ }^{6}$ In Malaysia, it can be found in mangrove swamps, particularly in Peninsular Malaysia. A few Melaleuca species harbor essential oils that are broadly utilized as therapeutic products, insecticides, and body care products. ${ }^{7}$ Adult $M$. cajuputi grows up to $33 \mathrm{~m}$ in height and are characterized by a slender crown. The tree is normally an unattached stem but may develop into collective stems. It can be easily recognized by a pure-white papery bark and thin strips as an outer layer. The leaves are gray-green in color, 4-10 cm long and $2 \mathrm{~cm}$ wide, firm, and have a pleasant scent. The flowers are whitishpink or purple in color when bloom. The seeds are firmly encircled and joined. Stems are enclosed in grayish-brown woody capsules. M. cajuputi essential oils are isolated from the leaves via simple steam distillation. These essential oils are either colorless or pale yellow in color and release camphor (menthol)-like aroma with a moderately bitter taste. This odor makes M. cajuputi essential oils anti-insecticidal because the aroma expels the mosquitoes. They are also prescribed as mucus expectorant and as medication for bronchitis. In Australia, the leaves are used for various types of ill-treatment for centuries. In Asia, its oil is customarily used to diminish joint discomfort, stiff joints, and rheumatism, and used as a mosquito repellent. Interestingly, water from the boiled leaves could relieve pain and jaundice. Meanwhile, the shoots can be eaten as a salad. ${ }^{8}$

According to a study by Hyldgaard et al, $p$-cymene is the most abundant compound in Cajaput essential oils. ${ }^{9}$ This compound might potentially act as a substitutional impurity, which partly disturbs the cytoplasmic membrane of bacteria. Phytochemical analysis revealed that $\alpha$-pinene, limonene, aterpinene, and 4-terpineol extracted from $M$. cajuputi leaves have antibacterial, anti-inflammatory, anodyne, and insecticidal properties. These phytochemical compounds are also used as cooking seasonings and aromatic agents in soaps, body care products, cleansers, and fragrances. M. cajuputi essential oils are also used to ease dental pain, headaches, seizures, and rheumatoid arthritis, and screen insects. ${ }^{10,11}$ In the present study, we focused on the antibacterial properties of the essential oils of $M$. cajuputi against five bacteria.

\section{MATERIALS AND METHODS \\ Plant material}

Information regarding plant collection is listed in Table 1. Plant authentication was performed by a competent botanist from the Universiti Sultan Zainal Abidin. In this study, 21 essential oils of different geographical origins were used.

\section{Extraction of essential oils}

The extraction yield of essential oils ranges from 0.2 to $0.3 \%$. Briefly, the essential oils were extracted from the fresh leaves via steam distillation for $4 \mathrm{~h}$. By utilizing water vapor at atmospheric pressure, the oil are refined from the leaves at a temperature below $100^{\circ} \mathrm{C}$, and the $4-\mathrm{h}$ extraction allows for the isolation and production of essential oil from the crude leaf samples. This process was followed by mixing the sample with distilled water and boiling at $100^{\circ} \mathrm{C}$ in a distillation flask. The emulsion of oil and water was permitted 


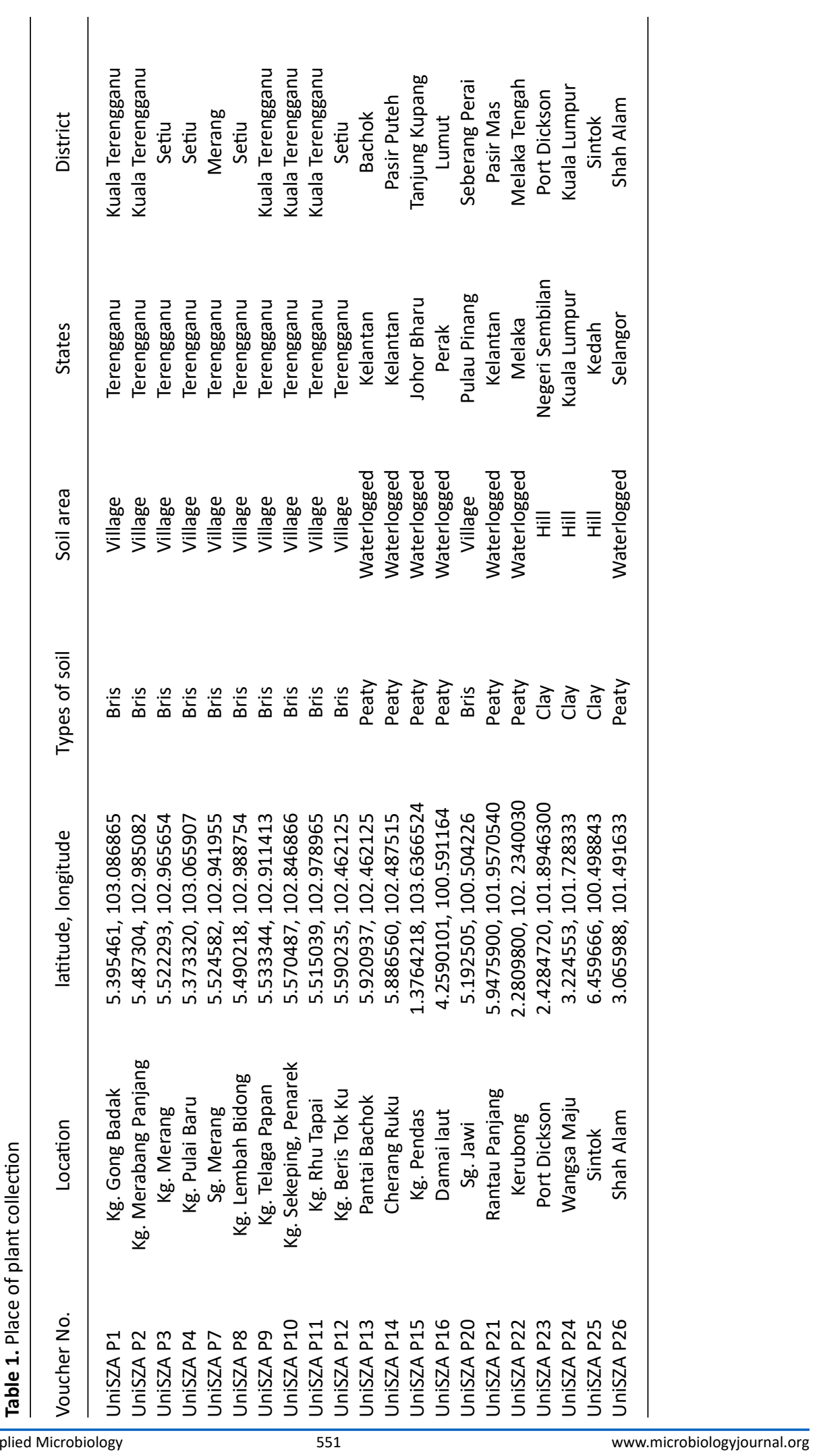


for $4 \mathrm{~h}$ to guarantee the segregation of oil layers and water. The oil yield was transferred into an amber bottle. The proportion of essential oils was determined and stored at room temperature until further use. The oil samples were then analyzed using FTIR and GCMS according to Zainon et al. with some modifications. ${ }^{12}$

\section{Determination of the extraction yield of essential oils}

Chemometric analysis was performed using the spectroscopic data to assess the spatial variations of the $21 \mathrm{M}$. cajuputi essential oils. Spectroscopy techniques are used for phytochemical identification and provide significant information regarding the qualitative and quantitative composition of essential oils, as well as their pattern recognition using chemometrics. Hierarchical cluster analysis was used to differentiate the samples. To evaluate the samples, the similarity between the spectral fingerprints was determined using similarity analysis (SA), which is based on correlation coefficients $r$.

\section{Test organisms}

The bacterial species used as test organisms were Staphylococcus aureus (ATCC 11632), Streptococcus pyogenes, and clinical isolates of methicillin-resistant Staphylococcus aureus (MRSA), Escherichia coli (ATCC 10536), and Klebsiella pneumoniae (ATCC 10031). All stock cultures were obtained from the Faculty of Medicine, Microbiology Laboratory, Universiti Sultan Zainal Abidin.

\section{Preparation of microbial cultures}

All tested bacterial strains were cultured in nutrient agar and broth. Bacterial suspensions were prepared by inoculating the nutrient broth with each of the bacterial cultures and incubated overnight at $37^{\circ} \mathrm{C}$.

\section{Antibacterial assay}

Antibacterial activity assay was performed using the disc diffusion method. The test organisms were cultured on sterile Petri dishes containing nutrient agar for $18-24$ hours at $37{ }^{\circ} \mathrm{C}$. On the next day, the cultures were adjusted to match 0.5 McFarland standards using normal saline. Then, a sterile cotton swab was dipped into each bacterial suspension and streaked onto MHA plates. Blank discs that were already impregnated with essential oil and distilled water (negative control) were placed on the surface of the agar using forceps. A chloramphenicol disk was used as a positive control. The three discs were placed on each plate and labelled correctly. The plates were incubated at $37{ }^{\circ} \mathrm{C}$ for $24 \mathrm{~h}$. A clear zone indicated growth inhibition, and the diameter of the zone was measured in millimeters using a ruler. The test was performed in triplicate. ${ }^{13}$

\section{Minimum inhibitory concentration (MIC)}

The minimum inhibitory concentration (MIC) of the M. cajaputi essential was determined by performing MIC using a 96-well microtiter

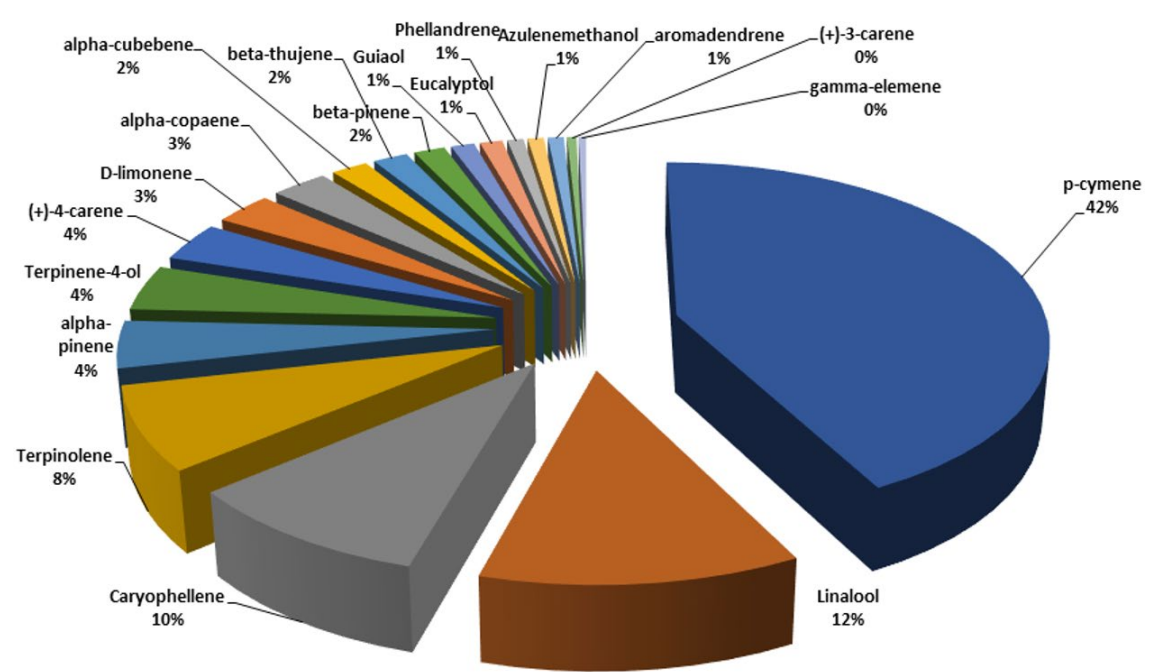

Fig. 1. Fraction of chemical compounds identified from Melaleuca cajuputi essential oils in Peninsular Malaysia. 
Table 2. Zone of inhibition $(\mathrm{mm})$ for disc diffusion method of the essential oils of $M$. cajuputi against selected bacteria

\begin{tabular}{lccccc}
\hline & \multicolumn{5}{c}{ Zone of inhibition $(\mathrm{mm})$} \\
& S. aureus & S. pyogenes & MRSA & E. coli & K. pneumoniae \\
Essential oil 0.714\% (w/w) & 12.7 & 10.7 & 10.0 & 8.7 & 9.3 \\
$\begin{array}{l}\text { Distilled water (negative control) } \\
\text { Chloramphenicol } \\
\text { (positive control) }\end{array}$ & 6 & 6 & 6 & 6 & 6 \\
\hline
\end{tabular}

Tests were performed in triplicate.

plate. ${ }^{14}$ The highest concentration of essential oils used was $0.714 \%(w / w)$. For the positive control, 1 $\mathrm{mg} / \mathrm{L}$ to $512 \mathrm{mg} / \mathrm{L}$ chloramphenicol was prepared. The negative control was prepared using $100 \mu \mathrm{L}$ of $\mathrm{MHB}$ inoculated with the bacteria and $100 \mu \mathrm{L}$ of $10 \%$ methanol. Then, the microtiter plate was incubated for $24 \mathrm{~h}$ at $37^{\circ} \mathrm{C}$.

\section{RESULTS}

A total of 19 compounds were identified from the essential oils of $M$. cajuputi leaves (Fig. 1). Moreover, the essential oils exhibited antibacterial activity against $S$. aureus, $S$. pyogenes, MRSA, K. pneumoniae, and E. coli (Table 2), with inhibition zones ranging from 8.7 to $12.7 \mathrm{~mm}$. Chloramphenicol disk was used as a positive control, and distilled water was used as a negative control. The largest inhibition zone $(12.7 \mathrm{~mm}$ ) was observed against $S$. aureus, followed by S. pyogenes $(10.7 \mathrm{~mm})$, MRSA $(10.0 \mathrm{~mm}), K$. pneumoniae $(9.3 \mathrm{~mm})$, and $\mathrm{E}$. coli $(8.7 \mathrm{~mm})$.

Next, MIC was used to measure the efficacy of the extracts against the tested bacterial strains. MIC was for the tested bacteria, which showed a zone of inhibition and were susceptible to the essential oils of $M$. cajuputi in the earlier antibacterial assay using the disc diffusion method. Results showed that the essential oils of $M$. cajuputi showed promising antibacterial activities. The MIC of the essential oils against $E$. coli and $K$. pneumoniae was $0.714 \%$. Similarly, the MICs against Gram negative bacteria (S. aureus, $S$. pyogenes, and MRSA) were also $0.714 \%$ (Table 3 ).
Table 3. MIC value of M. cajuputi essential oils

\begin{tabular}{ll}
\hline Tested bacterial strains & MIC (\%) \\
\hline S. aureus & 0.714 \\
S. pyogenes & 0.714 \\
MRSA & 0.714 \\
K. pneumoniae & 0.714 \\
E. coli & 0.714 \\
\hline
\end{tabular}

Tests were performed in triplicate.

\section{DISCUSSION}

The phytochemical compounds found in $M$. cajuputi essential oils were determined using FTIR and GC-MS. Nineteen compounds, namely p-cymene, linalool, caryophellene, terpinolene, alpha-pinene, terpinene-4-ol, (+)-4-carene, D-limonene, alpha-copaene, alphacubebene, beta-thujene, beta-pinene, guiaol, eucalyptol, azulenemethanol, phellandrene, aromadendrene, (+)-3-carene, and gammaelemene, were identified. The highest compounds found in $M$. cajuputi essential oils were p-cymene, followed by linalool and caryophellene. $p$-Cymene is the main antimicrobial compound in M. cajuputi essential oils. Several studies have suggested that this monoterpene possesses antibacterial, antiviral, and antifungal activities. ${ }^{15}$ Furthermore, previous studies have shown that linalool has anxiolytic, anti-cholesterol, and antibacterial activities. ${ }^{16-17}$ Aelenei et al. demonstrated that linalool alone or in combination with antibiotics showed antibacterial activity against Gram positive 
and Gram negative ${ }^{18}$. Meanwhile, the antimicrobial effect of $\beta$-caryophyllene was previously examined against human pathogenic bacterial and fungal strains. The results showed that $\beta$-caryophyllene demonstrated selective antibacterial activity against $S$. aureus and had a more pronounced antifungal activity than kanamycin. ${ }^{19}$ Therefore, our results showed that $M$. cajuputi essential oils were effective in inhibiting Gram positive and Gram negative bacteria.

Essential oils can inhibit the growth of various types of pathogens because of the existence of natural substances produced by plants. ${ }^{20}$ The phytochemical composition of essential oils is heterogeneous and comprises 20-60 different bioactive compounds. ${ }^{21}$ Essential oils and their components are hydrophobic, which makes them promising antimicrobial agents. This characteristic allows them to be separated from lipids, which are constituents of the cell membrane of bacteria and mitochondria. Thus, the disruption of cell structures renders the cell membrane more permeable, which causes the leakage of critical molecules and ions from the bacterial cell. As a result, the bacteria eventually die. Some compounds aim for the efflux mechanisms in Gram negative bacteria to regulate drug resistance. ${ }^{22}$

In this study, we determined the antibacterial activities of essential oils of $M$. cajuputi against Gram positive (S. aureus, $S$. pyogenes, and MRSA) and Gram negative ( $K$. pneumoniae and $E$. coli) bacteria using the disc diffusion and MIC assays. The results revealed that the essential oils of $M$. cajuputi intensively inhibited Gram positive bacteria compared to Gram negative bacteria, wherein the inhibition zones against Gram positive bacteria were greater than those in Gram negative bacteria. This is due to the more comprehensible cell walls of Gram positive bacteria. These findings are of great significance, especially in cases of $S$. aureus and clinical isolates of MRSA that are prominent for being resistant to some antibiotics. In addition, these organisms have the ability to produce several types of enterotoxins that can cause serious infections, leading to sepsis or death. ${ }^{23}$ The efficacy of essential oils depends on the structure of the target bacteria. According to a study by Swamy et al. essential oils easily penetrate the bacterial cell membranes and destabilize cellular architecture. ${ }^{24}$ The disruption of the membrane integrity is caused by an increase in bacterial cell membrane permeability, resulting in the leakage of cellular components, loss of ions, and disruption of many cellular activities. Gram negative bacteria have an advanced tolerance toward hydrophobic antimicrobial substances because their outer membrane encloses hydrophilic lipopolysaccharides, which block macromolecules and hydrophobic substances like those found in essential oils. This differentiating character of the cell wall makes Gram positive bacteria more sensitive to distinctive substances than Gram negative bacteria. Therefore, Gram negative bacteria are ordinarily less sensitive than Gram positive bacteria. Interestingly, our results were similar to that reported by Al-Abd et al., wherein $M$. cajuputi flower and leaf extracts were found to have a wide range of antimicrobial potential against Gram positive bacteria. ${ }^{25}$ However, they did not observe inhibition zones against the Gram negative bacteria tested. The differences in these findings are probably due to the distinctive solvent types that were used to extract phytocomponents from plant materials. ${ }^{26}$ Bioactive phytocomponents present in plants are proven and confirmed to be simulated using extraction approaches and extraction solvent systems ${ }^{27,28}$.

Conventional medication practices in old-world human cultures worldwide have shown that plants are beneficial sources of potent antimicrobial agents. For this reason, scientific studies have been conducted on the antimicrobial activities of plant extracts against various types of microorganisms, which have arisen in the evolution of alternative plant-based antimicrobial pharmaceutical medicines. ${ }^{29,30,31,32}$ Extracts and some natural phytoconstituents found in the Myrtaceae family have been reported to have anticancer, antimicrobial, antioxidant, and anti-inflammatory properties. ${ }^{33,34,35,36}$ Qualitative determination of phytochemicals showed the presence of flavonoids, saponins, and condensed tannins in all parts of this plant. ${ }^{37,38}$ The monoterpene content of essential oils is mainly composed of melaleucol, $\beta$-caryophyllene, terpinolene, g-terpinene, and plathyllol. ${ }^{39,40}$ Therefore, the antibacterial activity of the essential oils M. cajuput used in this study corresponded with their phytochemical contents. 


\section{CONCLUSION}

Essential oils of $M$. cajuputi possess antibacterial properties against diverse clinical isolates and can be used as a medication for several bacterial diseases. Nonetheless, further studies are required to explore their efficiency in suppressing the growth of pathogenic microorganisms.

\section{ACKNOWLEDGMENTS}

The authors would like to thank Universiti Sultan Zainal Abidin, Malaysia for the facilities and laboratory instruments.

\section{CONFLICT OF INTEREST}

The author declares that there is no conflict of interest.

\section{AUTHORS' CONTRIBUTION}

All authors listed have made a substantial, direct and intellectual contribution to the work, and approved it for publication.

\section{FUNDING}

None.

\section{DATA AVAILABILITY}

All datasets generated or analysed during this study are included in the manuscript.

\section{ETHICS STATEMENT}

Not applicable.

\section{REFERENCES}

1. Ali B, Al-Wabel NA, Shams S, Ahamad A, Khan SA, Anwar, F. Essential oils used in aromatherapy: A systemic review. Asian Pac J Trop Biomed. 2015;5(8):601-611. doi: 10.1016/j.apjtb.2015.05.007

2. Altemimi A, Lakhssassi N, Baharlouei A, Watson DG, Lightfoot DA. Phytochemicals: Extraction, isolation and identification of bioactive compounds from plant extracts. Plants. 2017;6(4):42. doi: $10.3390 \% 2$ Fplants 6040042

3. Edris AE. Pharmaceutical and therapeutic potentials of essential oils and their individual volatile constituents: A review. Phytother Res. 2007;21(4):308-323. doi: 10.1002/ptr.2072

4. Wińska K, Mączka W, Łyczko J, Grabarczyk M, Czubaszek A, Szumny A. Essential oils as antimicrobial agents-myth or real alternative?. Molecules. 2019;24(11):2130. doi: 10.3390\%2Fmolecules24112130

5. Jimbo D, Kimura Y, Taniguchi M, Inoue M, Urakami K. Effect of aromatherapy on patients with Alzheimer's disease. Psychogeriatrics. 2009;9(4):173-179. doi: 10.1111/j.1479-8301.2009.00299.x
6. Patramurti C, Amin R, Nastiti CMRR, Hariono MA. Review on the potency of leavessolid waste in wood preservation and its in silico prediction upon biological activities. Int J For Res 2020;2020:8885259. doi: 10.1155/2020/8885259

7. Amri I, Mancini E, De Martino L, et al. Chemical composition and biological activities of the essential oils from three Melaleuca species grown in Tunisia. Int. J. Mol. Sci. 2012;13(12);16580-16591. doi: 10.3390/ ijms131216580

8. Daud D, Gan NNMS, Ali MTM, Tawang A. The efect of Melaleuca cajuputi methanolic leaves extract on body growth, puberty and sperm quality of juvenile male rats. Indian J Biotechnol. 2015;11:115-119. https:// www.researchgate.net/publication/294787464_The_ effect_of_Melaleuca_cajuputi_methanolic_leaves_extract_on_body_growth_puberty_and_sperm_ quality_of_juvenile_male_rats. Accessed October 10, 2021.

9. Hyldgaard M, Mygind T, Meyer RL. Essential oils in food preservation: Mode of action, synergies and interactions with food matrix components. Front Microbiol. 2012;3:12. doi: 10.3389/fmicb.2012.00012

10. Bakar AA, Ahmad H, Sulaiman S, Omar B, Ali RM. Evaluation of in vitro bioactivity of Melaleuca cajuputi Powell essential oil against Aedes aegypti (L.) and Aedes albopictus (Skuse). Sains Malaysiana. 2019;48(9):1919-1926. doi: 10.17576/jsm-2019-480913

11. Marrelli M, Amodeo V, Perri MR, Conforti F, Statti G. Essential oils and bioactive components against arthritis: A novel perspective on their therapeutic potential. Plants. 2020;9(10):1252. doi: 10.3390/ plants9101252

12. Mat Sharif Z, Kamal AF, Jalil NJ. Chemical composition of Melaleuca cajuputi Powell. IJAET. 2019;9(1):34793483. doi: 10.35940/ijeat.A2668.109119

13. Abdul-Wahab NZ, Shahar S, Abdullah-Sani H, Pihie, $\mathrm{N}$ Ibrahim AHL. Antioxidant, antibacterial and antiviral properties of Goniothalamus umbrosus leaves methanolic extract. Afr. J. Microbiol. Res. 2011;20(5):3138-3143. doi: 10.5897/AJMR10.758

14. Wahab NZA, Badya N, Ibrahim N, Kamarudin MKA. Phytochemistry and antibacterial activity of Cynometra cauliflora. Indian J Public Health Res Dev. 2019;10(4): 806-810. doi: 10.5958/0976-5506.2019.00795.2.

15. Marchese A, Arciola CR, Barbieri R, et al. Update on Monoterpenes as antimicrobial agents: A particular focus on p-Cymene. Materials. 2017;10(8), 947. doi: 10.3390/ma10080947

16. Cho SY, Jun HJ, Lee JH, Jia Y, Kim KH, Lee SJ. Linalool reduces the expression of 3-hydroxy-3-methylglutaryl CoA reductase via sterol regulatory element binding protein-2- and ubiquitin-dependent mechanisms. Febs Letters. 2011;585:3289-3296. doi: 10.1016/j. febslet.2011.09.012

17. Klein G, Rüben C, Upmann M. Antimicrobial activity of essential oil components against potential food spoilage microorganisms. Curr Microbiol. 2013;67:200208. doi: 10.1007/s00284-013-0354-1

18. Aelenei P, Rimbu CM, Guguianu E, et al. Coriander 
essential oil and linalool - interactions with antibiotics against Gram positive and Gram negative bacteria. Lett Appl Microbiol. 2019;68(2): 156-164. doi: 10.1111/lam.13100.

19. Dahham SS, Tabana YM, Iqbal MA, et al. The anticancer antioxidant and antimicrobial properties of the sesquiterpene $\beta$-caryophyllene from the essential oil of Aquilaria crassna. Molecules. 2015;20(7):1180811829. doi: 10.3390/molecules200711808

20. Dhifi W, Bellili S, Jazi S, Bahloul N, Mnif W. Essential oils' chemical characterization and investigation of some biological activities: A critical review. Medicines. 2016;3(4):25. doi: 10.3390/medicines3040025

21. Chouhan S, Sharma K, Guleria S. Antimicrobial activity of some essential oils-present status and future perspectives. Medicines. 2017;4(3):58. doi: 10.3390/medicines4030058

22. Donadio G, Mensitieri F, Santoro V, et al. Interactions with microbial proteins driving the antibacterial activity of flavonoids. Pharmaceutics. 2021;13(5):660. doi: 10.3390/pharmaceutics13050660

23. Boucher H, Miller LG, Razonable RR. Serious infections caused by methicillin-resistant Staphylococcus aureus. Clin Infect Dis. 2010;51(S2):S183-S197. doi: 10.1086/653519

24. Swamy MK, Akhtar MS, Sinniah UR. Antimicrobial properties of plant essential oils against human pathogens and their mode of action: An updated review. Evid Based Complement Alternat Med. 2016;2016:3012462. doi: 10.1155/2016/3012462

25. Al-Abd NM, Mohamed Nor Z, Mansor M, Azhar F, Hasan MS, Kassim, M. Antioxidant, antibacterial activity and phytochemical characterization of Melaleuca cajuputi extract. BMC Complement Altern Med. 2015;15:385. doi: 10.1186/s12906-015-0914-y

26. Mohan SM, Pandey B. Antimicrobial activity of Oxalis corniculata Linn. Int J Sci Res. 2016;5(7):575-578. https://www.ijsr.net/archive/v5i7/ART2016216.pdf Accessed October 6, 2021.

27. Truong D-H, Nguyen DH, Ta NTA, Bui AV, Do TH, Nguyen HC. Evaluation of the use of different solvents for phytochemical constituents, antioxidants and in vitro anti-inflammatory activities of Severinia buxifolia. J. FoodQual. 2019; 2019: 8178294. doi: $10.1155 / 2019 / 8178294$

28. Cowan MM. Plant products as antimicrobial agents. Clin. Microbiol. Rev. 1999;12(4):564-582. doi: 10.1155/2019/8178294

29. Wahab NZA, Azizul A, Badya N, Ibrahim N. Antiviral activity of an extract from leaves of the tropical plant
Cynometra cauliflora. Pharmacogn. J. 2021;13(3): 752-757. doi: 10.5530/pj.2021.13.96

30. Azizan NA, Wahab NZA, Mohamad NA, Shambely AS, Othman AS. Antimicrobial activity of Psidium guajava leaves extract against foodborne pathogens. Int. J. Psychosoc. Rehabil. 2020;24(7):318-326. doi: 10.37200/IJPR/V24I7/PR2700031

31. Thapi DB, Ramaite IDI, Anokwuru CP, van Ree T, Hoppe HC. in vitro studies on antioxidant and anti-parasitic activities of compounds isolated from Rauvolfia caffra sond. Molecules. 2020;25(17):3781. doi: 10.3390/ molecules 25173781

32. Wink M. Medicinal plants: A source of anti-parasitic secondary metabolites. Molecules. 2012;17(12):1277112791. doi: 10.3390/molecules171112771

33. Frauches NS, do Amaral TO, Largueza CBD, Teodoro AJ. Brazilian Myrtaceae fruits: A review of anticancer proprieties. Br. J. Pharm. Res. 2016;12(1):1-15. doi: 10.9734/BJPR/2016/26782

34. Siddique S, Perveen Z, Nawaz S, Shahzad K, Ali Z. Chemical composition and antimicrobial activities of essential oils of six species from Family Myrtaceae. J. Essent. Oil-Bear. Plants. 2015;18(4):950-956. doi: 10.1080/0972060X.2014.935020

35. Aleksic V, Knezevic P. Antimicrobial and antioxidative activity of extracts and essential oils of Myrtus communis L. Microbiol. Res. 2014;169(4):240-254. doi: 10.1016/j.micres.2013.10.003

36. Stefanello MÉA, Pascoal ACRF, Salvador MJ. Essential oils from neotropical Myrtaceae. Chem Biodivers. 2011;8(1):73-94. doi: 10.1002/cbdv.201000098

37. Salvador MJ, De-Lourenço CC, Andreazza NL, Pascoal ACRF, Stefanello MEA. Antioxidant capacity and phenolic content of four Myrtaceae plants of the South of Brazil. Nat. Prod. Commun. 2011;6(7):977-982. doi: $10.1177 \% 2 F 1934578 \times 1100600713$

38. Nassar MI, Aboutabl EA, Ahmed RF, El-Khrisy EA, Ibrahim KM, Sleem AA. Secondary metabolites and bioactivities of Myrtus communis. Pharmacognosy Res. 2010;2(6): 325-329. doi: 10.4103\%2F09748490.75449

39. Kim JH, Liu KH, Yoon Y, Sornnuwat Y, Kitirattrakarn T, Anantachoke C. Essential leaf oils from Melaleuca cajuputi. Acta Hortic. 2005;680(6):65-72. doi: 10.17660/ActaHortic.2005.680.8

40. Pino J, Bello A, Urquiola A, Aguero J. Marbot R. Chemical composition of cajuput oil (Melaleuca leucadendra L.) from Cuba. J. Essent. Oil Res. 2002;14(1): 10-11. doi: 10.1080/10412905.2002.9699744 